\title{
Proceeding
}

Supplementary Issue: Spring Conferences of Sports Science. III International Congress on Research and Didactics of Physical Education, 15-16 March 2018. Granada, Spain

\section{Design and validation of the questionnaire "GAMEPLAY" for the assessment of sports activities}

\author{
FÉLIX ZURITA-ORTEGA ${ }^{1} \triangle$, NURIA MEDINA MEDINA², RAMÓN CHACÓN-CUBEROS ${ }^{3}$, JOSÉ LUIS \\ UBAGO-JIMÉNEZ1 ${ }^{1}$ MANUEL CASTRO-SÁNCHEZ ${ }^{4}$, GABRIEL GONZÁLEZ-VALERO ${ }^{1}$ \\ ${ }^{1}$ Department of Didactics of Musical, Plastic and Corporal Expression, Faculty of Education Sciences, \\ University of Granada, Spain \\ ${ }^{2}$ Department of Software and Computing Systems, University of Granada, Spain \\ ${ }^{3}$ Department of Integrated Didactics, University of Huelva, Spain \\ ${ }^{4}$ Department of Education. University of Almería, Spain
}

\begin{abstract}
Knowledge of play is essential in the field of education and sport, the aim of this research work is to create an instrument in order to measure in a proper and reliable way the analysis of play in people who practise sports non-professionally, based on a multidimensional and hierarchical model of play. Validation of content has been carried out with the agreement and consensus of sixteen experts with a PhD degree in Physical Activity and Sports Science using the Delphi Method and validity of understanding has been established by the application of the questionnaire to a sample of 769 non-professional athletes/players aged between 21 and 51. Some changes were made based on initial data collected using the Delphi Method. The final test named GAMEPLAY was made up of 12 items which were suitably fit regarding validity of understanding and validity of content. Confirmatory factor analysis established three dimensions (usability, satisfaction and empathy). Key words: PLAY, SPORT, VALIDATION, SATISFACTION.
\end{abstract}

\section{Cite this article as:}

Zurita-Ortega, F., Medina, N., Chacón-Cuberos, R., Ubago-Jiménez, J., Castro-Sánchez, M., \& GonzálezValero, G. (2018). Design and validation of the questionnaire "GAMEPLAY" for the assessment of sports activities. Journal of Human Sport and Exercise, 13(2proc), S178-S188. doi:https://doi.org/10.14198/ihse.2018.13.Proc2.02

Corresponding author. Room 122.1. Department of Didactics of Musical, Plastic and Corporal Expression. Faculty of Education Sciences, University of Granada. Campus de Cartuja, s/n. CP. 18071 Granada, Spain.

E-mail: mcastros@ual.es

Supplementary Issue: Spring Conferences of Sports Science. III International Congress on Research and Didactics of Physical Education, 15-16 March 2018. Granada, Spain.

JOURNAL OF HUMAN SPORT \& EXERCISE ISSN 1988-5202

(C) Faculty of Education. University of Alicante

doi: 10.14198/jhse.2018.13.Proc2.02

S178 | 2018| Proc2 | VOLUME 13

C 2018 University of Alicante 


\section{INTRODUCTION}

Numerous research studies confirm the importance of play for the human being especially during preschool period or in marginal sectors (Gutiérrez, 2004; Chacón-Cuberos, Arufe, Cachón, Zagalaz \& Castro, 2016) be it in a ludic context (Alonso, Carranza, Rueda \& Naranjo, 2014; Tuñon, Laiño \& Castro, 2014), in the context of sports (Zurita-Ortega, Romero, Ruiz, Martínez, Fernández \& Fernández, 2008; Jiménez-Torres, GodoyIzquierdo \& Godoy, 2012) or in the context of digital leisure (Chacón-Cuberos, Castro, Zurita-Ortega, Espejo \& Martínez, 2016; Viñals \& Cuenca, 2016).

However, in the context of sports with a certain level of dedication, scarce interest is detected towards playful aspects in the different activities. One of the reasons why scant studies on this group are found (García-Mas et al., 2015; Castillo-Jiménez, López-Walle, Tomás \& Balaguer, 2017) is among others the scarce involvement of non-professional athletes in tasks unconnected to their category. Learning about a new speciality in physical activity entails the integration and observance of needs and the exchange and acquisition of resources, either individual or collective.

We could talk about gameplay, which is a concept originated in the field of video games (González-Sánchez, Gutiérrez-Vela, Montero-Simarro \& Padilla-Zea, 2012) and which marks the design and analysis of games, encompassing from quality of the games to rules, as well as player's experiences during interaction. Regarding physical activity and motor skills, it has been kept in mind for a long time the importance of its playful nature, which should influence its practice and especially younger people. In this regard ChacónCuberos et al. (2016) pointed out the importance of the learning of video games in relation to sports and physical activity for future teachers. The aforementioned suggests the need to set up a tool which can establish the abilities to learn new games or categories of sports from the field of gameplay.

The instruments used to assess play most widely mentioned and used in Spanish and English language were analysed, specifically Lavega, March \& Filella (2013) validated a scale regarding sports games and emotions based on four assumptions about motor skills focused on Physical Education, evaluating positive emotions (happiness, mood, love, joy), negative emotions (anger, rejection, fear, anxiety, embarrassment and sadness) and ambiguous emotions (compassion, surprise and hope). In the same way Romero-Martín, GelpiFleta, Mateu-Serra \& Lavega-Burgués (2017), validated the rating scale POMS to assess mood states using emotional dimensions, previously addressed by Andrade-Fernández, Arce-Fernández \& Seaone-Pesqueira (2002) in their study with athletes; we also have to point out the work by Arruza, Arribas, González, Balagué, Romero \& Ruiz (2005) who establish a test on decision-making styles in sports (CETD) regarding aspects such as recognition of emotions, utilisation of emotions in order to solve problems or empathy among others.

Consequently, based on the aforementioned works, it seems advisable to imagine a model which is nonobservable directly, making it necessary to deduce it regarding behaviour or basing it on what the person thinks about himself, therefore the degree to which a person considers certain closed sentences relate to himself is assessed, having these sentences the advantage of being simple because of their directness and easy application. In order to choose the instrument two options arise, on the one hand to use an already existing instrument and on the other hand to create a new one trying therefore to improve its design and validation (McCarthy, Jones \& Clark-Carter, 2008; Scotto, Guillet-Descas, Procentese \& Martinent, 2017).

At an earlier age Rose, Larkin, Hands, Howard \& Parker (2009) and Ruiz-Ariza, Ruiz, De la Torre-Cruz, Latorre-Román \& Martínez-López (2016), established the level of attraction towards physical activity in children and teenagers, and having assessed their appropriateness to be used in our research study 
according to degree of adaptation to our intentions, it was confirmed that none of them seemed appropriate to be used for different reasons: a) Vocabulary used is normally difficult to understand and childish for athletes; b) Many items are too long; c) In general the instruments are hardly motivating; d) Contexts are too broad not including the context of sports; e) The questions are sometimes too long and formulated in the negative thus complicating comprehension; f) Answers with more than five options which increase the number of possibilities thus making it more difficult for respondents to make a decision; and g) sports characteristics in respondents have not been taken into account.

Considering the lack of scales, questionnaires or tests adapted to Spanish reality regarding the concept of gameplay and not entirely adapted to athletes, a new instrument is elaborated, in a population sharing characteristics, therefore providing higher levels of validity to investigations in the context of non-professional athletes and offering data to compare with previous studies. The goals pursued by this research study are: a) The study of content validity by means of the agreement and consensus of experts using the Delphi method; b) Establish the level of understanding of the instrument by means of its application to a sample of non-professional athletes; c) Analyse reliability of the questionnaire; and d) Confirm the multidimensionality of the construct by means of a Confirmatory Factor Analysis (CFA).

\section{MATERIALS AND METHODS}

\section{Participants}

The use of experts as a strategy for the valuation and assessment of instruments is rather common in educational investigation and it is an essential and basic part of the Delphi Method (Cabero \& Barroso, 2013), which has been widely used in numerous investigations (Boza \& Méndez, 2013; Mérida, Serrano \& Tabernero, 2015). According to what their works suggest (Pozo, Gutiérrez \& Rodríguez, 2007), two human groups in charge of the validation of the designed instrument were formed, on the one side the coordinating group and on the other side the group of experts, the former made up of the members of this investigation who share the characteristics of knowing the technique, being researchers related to this topic (graduates in Physical Education) and having the ability to intercommunicate (Mira, Padrón \& Andrés, 2010), the second group (experts) was constituted attending to different guidelines (Brill, Bishop \& Walker, 2006), such as the expert's connection to the subject matter, the expert's professional experience, personal features and professional expertise. Based on this, the group of selected experts is made up of university professors and renowned researchers in this field. It is pointed out that the suitable number must range from 7 to 30 experts, taking part in this study 16 experts, all of them university professors with a doctorate and a degree in Physical Education (43.8\% men and 56.3\% women) with an average experience of 19.3 years in university education.

Based on the aforementioned, a methodological sequence was established, structured in three phases: preliminary, exploratory and final.

In the preliminary phase, the coordinating group delimits the research problem, establishes the selection of experts (obtaining their collaboration commitment), interprets partial and final results of the investigation and makes convenient adjustments and corrections.

In the exploratory phase, the design of the questionnaire in its experimental adaptation and the setting of the final version was carried out. The first version was subjected to a round of analysis and discussion by the members of the coordinating group who established the adjustments and corrections needed by means of the qualitative criteria achieving greater consensus. This version was validated in a second round by the group of chosen experts, with the intention of getting information from the most stable quantitative and 
qualitative criteria, therefore, experts were selected and invited and the questionnaire was sent to them by email where a short introduction was written on the first page explaining the object of research along with a record sheet where personal information was recorded, in addition to the explanation of the aims of the questionnaire and the way to fill in the instrument and finally the questionnaire for its validation. The questionnaire uses a Likert scale with three options (high, medium and low) depending on the degree of adaptation or sense of belonging of the item and the dimension to be investigated, an open question is also brought up in order to get a qualitative valuation about considered items. They are asked to answer within 30 days. During this month people are followed up, completed scales are recorded and the information is analysed by the coordinating group.

In the final phase, results of the whole validation process of the final version of the questionnaire are summarised in order to subsequently apply them to 769 non-professional athletes aged between 21 and 51 , of which $522(67.88 \%)$ were men and $247(22.12 \%)$ were women.

\section{Procedure}

Construction of the instrument

As soon as the limitations of the questionnaires and instruments available were analysed we decided to create the questionnaire GAMEPLAY, establishing as prior requirements those set out in works by Ramos, Giménez, Lapay \& Muñoz (2006) such as: a) Concision (few items); b) Simplicity (concerning its application); c) Comprehensible vocabulary adapted to the characteristics of the sample; d) Short questions without negatives and with closed options; e) Attractive design with theoretical support.

General procedure in the elaboration of the questionnaire GAMEPLAY

The scale has been formed and created based on the conditions of an instrument for psychological assessment suggested by Fernández-Ballesteros (1995) and Cronbach (1990). Contents have been determined based on bibliographic reviews and experts' opinions (Crocker \& Algina, 1986), according to established recommendations and by means of closed questions and five options of answer.

\section{Creation of the questionnaire GAMEPLAY}

Based on an initial set of items proceeding from various questionnaires and scales related to games and other dimensions of ludic aspects of sports with which the concept developed is closely related, the coordinating group created a first experimental version removing some items and dimensions that could lead to misunderstanding and complicated the global understanding of the questionnaire.

Each question is formulated with the parameters: I have not liked it at all, I have not liked it much, I have liked it a little, I have liked it a lot, I have loved it. Next, each item was read and classified in the dimensions: usability, empathy and satisfaction. The choice was made based on its suitability using a rational criterion obtaining a total of 12 items which are the basis for the development of the questionnaire in its first version. These issues had different origins, some were obtained literally from the original instruments, others were reformulated and others were specifically written for this test. The questions were distributed alternating dimensions and the option was closed from 1 to 5 .

Content validity of the instrument

In order to study the validity of the questionnaire, content validity was defined as well as the degree to which a test represents adequately what has been carried out (Thomas \& Nelsson, 2007). In order to achieve optimal levels of content validity the technique of experts was used as well as a pilot study in order to be able to know the validity of understanding of respondents. The experts were entrusted with the valuation of initial 
information, the questions and the general valuation of each of them, based on the level of understanding and adaptation of the wording.

Regarding items, a series of statistical indicators were considered, such as the discrimination index and statistic descriptive of each of the items. With the aim of giving data sufficient veracity it is considered necessary to carry out a study of reliability and validity, the latter will comply with psychometric requirements with a satisfactory Cronbach's reliability coefficient and a confirmatory factor analysis (Cronbach, 1990 and Muñiz, 1998). In order to check all this we used the statistical programmes SPSS 24.0, FACTOR Analysis 9.3.1 and M-PLUS7.

\section{Validity of understanding of the instrument}

In order to check validity a pilot study was carried out and following its application to 769 non-professional athletes (with a duration of 5 to 6 minutes), a level of understanding from a qualitative perspective was established, recording queries and suggestions arisen regarding the questionnaire.

\section{Data analysis}

Content analysis has been used to analyse qualitative data, concerning quantitative data, the analysis of statistic descriptive and the estimation of the internal consistency has been done using programme SPSS 24.0, the EFA (Exploratory Factor Analysis) has been carried out using FACTOR Analysis 9.3.1 and the CFA (Confirmatory Factor Analysis) with M-PLUS 7.

\section{RESULTS}

As regards results concerning content validity of the instrument, data obtained using qualitative techniques were treated by means of content analysis with the aim of obtaining evidence in relation to conceptual, cultural and linguistic validity of the questionnaire GAMEPLAY. Qualitative contributions are completed with quantitative contributions given by experts on each item. Integration of contributions from both groups with independent sources guarantee the adequacy of the instrument.

From the 12 items in the questionnaire, 7 do not undergo modification since experts' rating is near 3 and none of them suggest any alternative, and the remaining 5 , rated around 2 , are modified following contributions and opinions of the experts' group reaching an agreement with the coordinating group for the final composition.

For the exploratory factor structure the SPSS 24.0 and the FACTOR Analysis 9.3 .1 were used, in this first part of the analysis of results descriptive values of the study have been calculated, and experts' recommendations have been followed (Schmider, Ziegler, Danay, Beyer \& Bühner, 2010), not removing any item since figures higher than 2 are not found in dispersion tests (asymmetry and kurtosis) as shown in Table 1.

Subsequently, by means of the programme FACTOR Analysis (Lorenzo-Seva \& Ferrando, 2006), as shown in Table 2, three factors have rotated for the pilot test. Bartlett's test [3658.4 ( $d f=66 ; p=0.000)]$ and KaiserMeyer-Olkin's $(\mathrm{KMO})$ test $=0.897$, used to verify if the sample comes from population with the same variance and if it has a good sampling adequacy, indicate a good adjustment of data in order to subject them to factor analysis. The three extracted factors explain the $62.6 \%$ of the total variance, the CFI (comparative fit index) scored 0.96, the goodness of fit index (GFI) scored 0.99, the AGFI also 0,99 and the root mean square residual (RMSR) 0.027. All these data denote an excellent fit for those items. For the analysis of reliability 
Cronbach's Alpha has been calculated obtaining a value of 0.867 in the general scale and other higher than 0.700 (except factor 2 with a value close to it).

Table 1. Descriptive in the test "GAMEPLAY"

\begin{tabular}{|c|c|c|c|c|c|}
\hline & M & SD & $\mathbf{V}$ & A & $\mathrm{K}$ \\
\hline $\begin{array}{l}\text { V01. Indicate degree to which you found it easy to learn } \\
\text { how to play }\end{array}$ & 3,60 &, 944 & 890 & $\overline{-}, 360$ & ,375 \\
\hline V02. Indicate degree to which you found it easy to play & 3,46 & ,925 & ,855 & 281 &, 522 \\
\hline $\begin{array}{l}\text { V03. Indicate degree to which you liked the context of the } \\
\text { game (area, equipment,...) }\end{array}$ & 3,47 & 1,083 & 1,174 & , 364 & $\begin{array}{l}- \\
\end{array} 524$ \\
\hline $\begin{array}{l}\text { V04. Indicate degree to which you liked the cooperative } \\
\text { part of the game (team, rivals...) }\end{array}$ & 3,24 & 1,139 & 1,297 & - &,- 557 \\
\hline $\begin{array}{l}\text { V05. Indicate degree to which you liked the rules } \\
\text { suggested for the game }\end{array}$ & 3,73 & 1,114 & 1,241 & ,676 & , 264 \\
\hline $\begin{array}{l}\text { V06. Indicate degree to which you liked interaction with } \\
\text { other players }\end{array}$ & 3,21 & 1,125 & 1,267 & - & - \\
\hline $\begin{array}{l}\text { V07. Indicate degree to which you liked challenges of the } \\
\text { game }\end{array}$ & 3,68 & 1,067 & 1,139 & -6 &,- 329 \\
\hline $\begin{array}{l}\text { V08. Indicate degree to which you liked interaction with the } \\
\text { game }\end{array}$ & 3,35 & 1,059 & 1,121 & - & - \\
\hline $\begin{array}{l}\text { V09. Indicate degree to which you liked the scoring of the } \\
\text { game }\end{array}$ & 3,29 & 1,129 & 1,275 &,- 258 & -608 \\
\hline $\begin{array}{l}\text { V10. Summarizing, indicate degree to which you liked the } \\
\text { game }\end{array}$ & 3,83 & 1,055 & 1,113 & , 730 & ,095 \\
\hline V11. Indicate degree to which you understood how to play & 3,55 & 978 & ,956 & 439 & - \\
\hline $\begin{array}{l}\text { V12. Indicate degree to which you feel identified with this } \\
\text { game }\end{array}$ & 2,96 & 1,239 & 1,536 & ,027 & , 956 \\
\hline
\end{tabular}
Note 1: M, Median; SD, Standard Deviation; V, Variance; A, Asymmetry; K, Kurtosis

Table 2. Factor weight of dimensions in the test "GAMEPLAY"

\begin{tabular}{llll|llll}
\hline Variables & F1 & F2 & F3 & Variables & F1 & F2 & F3 \\
\hline V 01 & $\mathbf{0 . 9 8 1}$ & -0.116 & -0.016 & V 01 & 0.981 & & \\
V 02 & $\mathbf{0 . 6 4 1}$ & -0.041 & -0.036 & V 02 & 0.641 & & \\
V 03 & 0.012 & 0.244 & $\mathbf{0 . 5 5 4}$ & V 11 & & 0.397 & \\
V 04 & 0.082 & -0.054 & $\mathbf{0 . 6 0 1}$ & V 12 & & 0.916 & \\
V 05 & 0.059 & 0.106 & $\mathbf{0 . 6 8 6}$ & V 03 & & & 0.554 \\
V 06 & 0.053 & 0.123 & $\mathbf{0 . 5 5 1}$ & V 04 & & & 0.601 \\
V 07 & -0.103 & -0.201 & $\mathbf{0 . 8 7 1}$ & V 05 & & & 0.686 \\
V 08 & 0.056 & 0.054 & $\mathbf{0 . 6 0 3}$ & V 06 & & & 0.551 \\
V 09 & -0.115 & 0.052 & $\mathbf{0 . 6 3 2}$ & V 07 & & & 0.871 \\
V 10 & -0.011 & 0.191 & $\mathbf{0 . 6 7 0}$ & V 08 & & & 0.603 \\
V 11 & 0.047 & $\mathbf{0 . 3 9 7}$ & 0.148 & V 09 & & & 0.632 \\
V 12 & -0.046 & $\mathbf{0 . 9 1 6}$ & -0.213 & V 10 & & & 0.670 \\
\cline { 5 - 8 } & & & & $\mathrm{a}=0.867$ & $\mathrm{a}=0.745$ & $\mathrm{a}=0.689$ & $\mathrm{a}=0.884$ \\
\hline
\end{tabular}


Once the reliability of the items and the validity of the instrument is confirmed by means of the EFA, the CFA is used, for that, the 12 selected questions were grouped in a previous theoretical structure of three components: usability, empathy and satisfaction, confirmed previously in the exploratory analysis. Finally the factorial structure has been analysed by means of a CFA where three factors were considered, this disposition is a priori what establishes that results of the model are fully confirmatory. In the same way as happened with EFA, indices show a reasonably suitable model fit. This way CFI scores 0.955 and TLI 0.942. C2 establishes a value of 3318.249 with 66 degrees of freedom. Finally the RMSEA evaluates the model as one with a good fit, being its index 0.061 . This way and jointly supported by all the indices mentioned (Figure 1 ), it can be confirmed that the model suggested shows a reasonable and acceptable closeness to data, and can contribute by supporting the hypothesis of the multidimensionality of the construct.

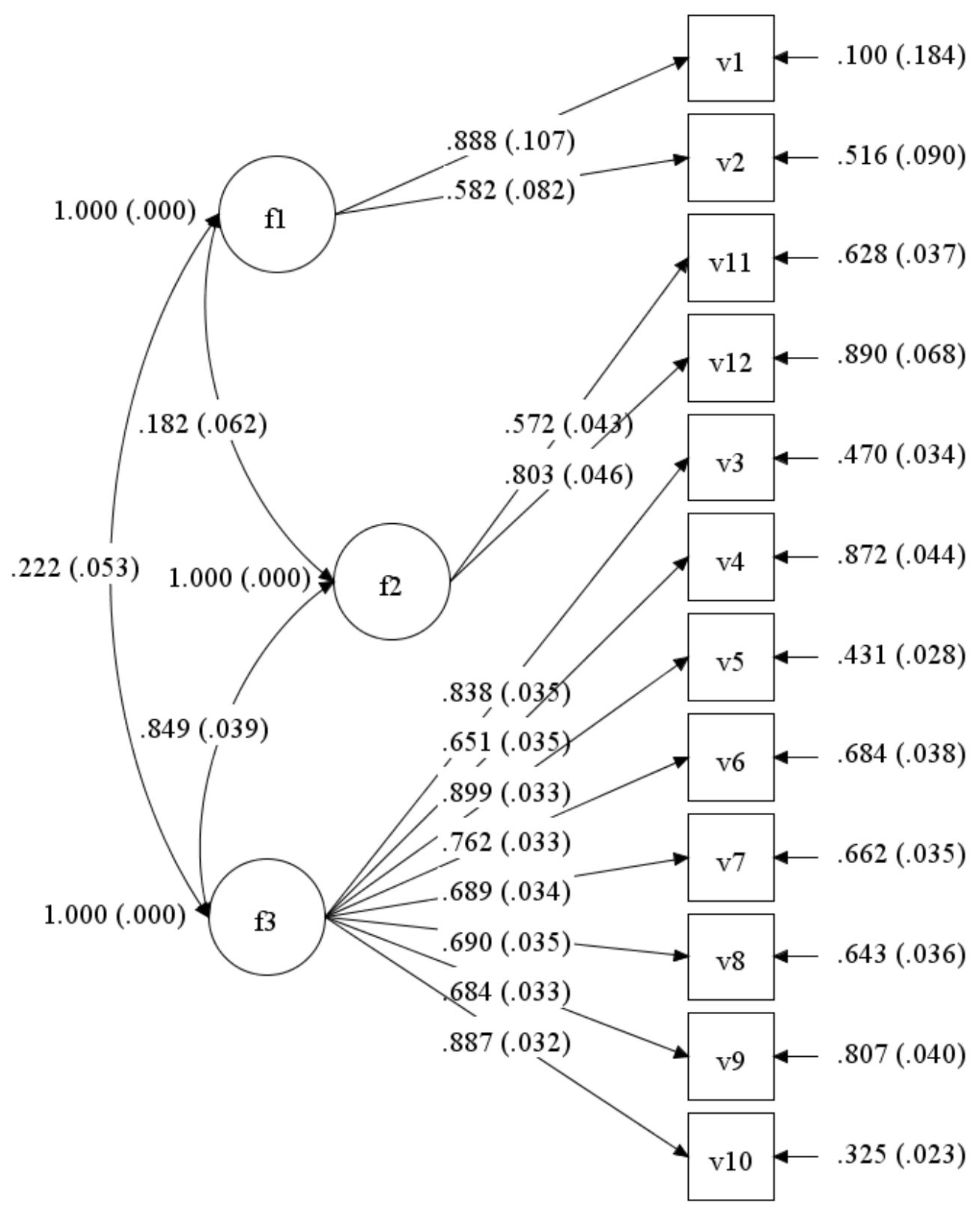

Figure 1. Confirmatory factor analysis of the test "GAMEPLAY" 
For all of these reasons an analytical review of factorial structure is developed, in such a way that estimations of factorial saturations for each of the items in their corresponding factors are illustrated in figure 1.

\section{DISCUSSION AND CONCLUSIONS}

The aim of this study was to analyse and validate the content of the instrument GAMEPLAY in a sample of non-professional athlete respondents. It must be pointed out that results obtained show a satisfactory metric quality of the questionnaire being evaluated by means of confirmatory analysis and they have shown a suitable fit to the model proposed. In short it can be noted that results denote the appearance of three factors: usability, empathy and satisfaction.

In the design and validation of the instrument we followed the phases that literature suggests both in general and in the context of sports (Bulguer \& Housner, 2007; Cabero \& Barroso, 2013; García, Antúnez \& Ibáñez, 2016; González-Espinosa, Ibáñez, Feu \& Galatti, 2017). Expert judges taking part in the validation of the instrument $(n=16)$ possess quality criteria being greater in number than in other similar studies, specifically the number of judges taking part in the study by Ortega, Jiménez, Palao \& Sainz (2008) was 12, and in the study by Robles, Robles, Giménez \& Abad (2016) it was 10.

It also has a suitable reliability regarding internal consistency, as much in the general questionnaire as in the three factors which facilitate its application in any sports field. Psychometric results of the factorial and reliability structure complement aspects of content validity and establish a good psychometric quality.

The three dimensions found enable the valuation of different aspects of play and how to confront it, given that there is an increasing disinterest of adults in new sports specialities and alternatives (Castillo-Jiménez et al., 2017). In this sense Chacón-Cuberos, Zurita-Ortega, Cachón, Espejo, Castro \& Pérez (2018) reflected in their work the fact that studying a degree related to physical activity has a positive effect on task, or what is the same on the knowledge of new activities, while Coterón, Franco, Pérez-Tejero \& Sampedro (2013) state that motivational climate oriented towards oneself is related to lower levels of interest on the learning of physical education.

The final structure of the questionnaire consists of three dimensions, to which a general gameplay index must be added, established by the addition of the twelve items in the questionnaire. Data obtained establish new perspectives of study on the importance of gameplay in adults, since the learning of new specialities and categories is usually produced in Pre-school, Primary or Secondary school stages (Lavega et al., 2013; Navarro-Patón, Barreal \& Basanta, 2016).

For all of these reasons this instrument must be considered as a tool favouring and enabling integration of the playful nature of sports activities as a comprehensive idea in the context of education (González-Valero, Zurita-Ortega \& Martínez-Martínez, 2017). The questionnaire GAMEPLAY not only provides empirical evidence but is also an instrument which can help teachers and coaches to define the levels of adaptability to new games and activities.

Future research should go in the direction of replicating the results found in this study with samples from other contexts. Among the main limitations of this study we find the sample analysed which fluctuated between different sports specialities, thus indicating a special inclination towards certain sports activities; besides, the ages of respondents were very heterogeneous which also affects the choice of preferences. 


\section{REFERENCES}

Alonso, F. J., Carranza, M. D., Rueda, J. D. \& Naranjo, J. (2014). Composición corporal en escolares de primaria y su relación con el hábito nutricional y la práctica reglada de actividad deportiva. Revista Andaluza de Medicina del Deporte, 7(4), 137-142. https://doi.org/10.1016/i.ramd.2014.08.001

Andrade-Fernández, E.M., Arce-Fernández, C. \& Seaone-Pesqueira, G. (2002). Adaptación al español del cuestionario «Perfil de los Estados de Ánimo» en una muestra de deportistas. Psicothema, 14(4), 708-713.

Arruza J.A., Arribas, S., González, O., Balagué, G., Romero, S. \& Ruiz, L.M. (2005). Desarrollo y validación de una versión preliminar de la escala de competencia emocional en el deporte (ECE-D). European Journal of Human Movement, 14, 151-163.

Boza, A. \& Méndez, J. M. (2013). Aprendizaje motivado en alumnos universitarios: validación y resultados generales de una escala. Revista de Investigación Educativa, 31(2), 331-347.

Brill, J. M., Bishop, M. J. \& Walker, A. E. (2006). The competencies and characteristics required of an effective project manager: A web-based Delphi study. Educational Technology Research and Development, 54(2), 115-140. https://doi.org/10.1007/s11423-006-8251-y

Bulguer, S. M. \& Housner, L. D. (2007). Modified Delphi investigation of exercise science in physical education teacher education. Journal of Teaching in Physical Education, 26, 57-80. https://doi.org/10.1123/itpe.26.1.57

Cabero, J. \& Barroso, J. (2013). La utilización del juicio de experto para la evaluación de TIC: el coeficiente de competencias experta. Bordón, 65(2), 25-38. https://doi.org/10.13042/brp.2013.65202

Castillo-Jiménez, N., López-Walle, J., Tomás, I. \& Balaguer, I. (2017). Relación del clima empowering con la motivación autodeterminada a través de la satisfacción de las necesidades psicológicas básicas. Revista de Psicología del Deporte, 26(3), 33-39.

Chacón-Cuberos, R., Arufe, V., Cachón, J., Zagalaz, M. L. \& Castro, D. (2016). Estudio relacional de la práctica deportiva en escolares según el género. SportK, 5(1), 85-92. https://doi.org/10.6018/249161

Chacón-Cuberos, R., Castro, M., Zurita-Ortega, F., Espejo, T. \& Martínez, A. (2016). Videojuegos activos como recurso TIC en el aula de Educación Física, estudio a partir de parámetros de ocio digital, Digital Education Review, 29, 112-123.

Chacón-Cuberos, R., Zurita-Ortega, F., Cachón, J, Espejo, T., Castro, M. \& Pérez, A. (2018). Clima motivacional percibido hacia el deporte en estudiantes universitarios de Educación Física. Apunts, 131(1), 49-59. https://doi.org/10.5672/apunts.2014-0983.es.(2018/1).131.04

Coterón, J., Franco, E., Pérez-Tejero, J. \& Sampedro, J. (2013). Clima motivacional, competencia percibida, compromiso y ansiedad en Educación física. Diferencias en función de la obligatoriedad de la enseñanza. Revista de Psicología del Deporte, 22(1), 151-157.

Crocker, L. \& Algina, J. (1986). Introduction to classical and modern theory. New York: Holt, Rinehart and Winston.

Cronbach, L. J. (1990). Essentials of Psychological Testing. New York: Harper and Row.

Fernández-Ballesteros, R. (1995). Cuestiones conceptuales básicas evaluación de programas. En R. Fernández-Ballesteros (Ed.). Evaluación y programas. Una guía práctica en ámbitos sociales, educativos de salud (pp.21-47). Madrid: Síntesis.

García, A., Antúnez, A. \& Ibáñez, S. J. (2016). Análisis del proceso formativo en jugadores expertos: validación de instrumento. Revista Internacional de Medicina y Ciencias de la Actividad Física y el Deporte, 16(61), 157-182.

García-Mas, A., Fuster-Parra, P., Ponseti, F. J., Palou, P., Olmedilla, A. \& Cruz, J. (2015). Análisis bayesiano de la motivación, el clima motivacional y la ansiedad en jóvenes jugadores de equipo. Anales de Psicología, 31(1), 355-366. https://doi.org/10.6018/analesps.31.1.167531 
González-Espinosa, S., Ibáñez, S. J., Feu, S. \& Galatti, L. R. (2017). Programa de intervención para la enseñanza deportiva en el contexto escolar, PETB u PEAB: Estudio preliminar. Retos, 31, 107-113.

González-Sánchez, J. L., Gutiérrez-Vela, F. L., Montero-Simarro, F. \& Padilla-Zea, N. (2012). Playability: analysing user experience in video games. Behaviour \& Information Technology, 31(10), 1033-1054. https://doi.org/10.1080/0144929X.2012.710648

González-Valero, G., Zurita-Ortega, F. \& Martínez-Martínez, A. (2017). Panorama motivacional y de actividad física en estudiantes: una revisión sistemática. Education, Sport, Health and Physical Activity- ESHPA, 1(1), 41-58.

Gutiérrez, M. (2004). El valor del deporte en la educación integral del ser humano. Revista de Educación, $335,105-126$.

Jiménez-Torres, M., Godoy-Izquierdo, D. \& Godoy, J. F. (2012). Relación entre los motivos para la práctica físico-deportiva y las experiencias de flujo en jóvenes: diferencias en función del sexo. Universitas Psychologica, 11(3), 909-920.

Lavega, P., March, J. \& Filella, G. (2013). Juegos deportivos y emociones. Propiedades psicométricas de la escala GES para ser aplicada en la Educación física y el Deporte. Revista de Investigación Educativa, 31(1), 151-165. https://doi.org/10.6018/rie.31.1.147821

Lorenzo-Seva, U. \& Ferrando, P. J. (2006). FACTOR: A computer program to fit the exploratory factor analysis model. Behavioral Research Methods, Instruments and Computers, 38(1), 88-91. https://doi.org/10.3758/BF03192753

McCarthy, P. J., Jones, M. V. \& Clark-Carter, D. (2008). Understanding enjoyment in youth sport: A developmental perspective. Psychology sport and exercise, 9(2), 142-156. https://doi.org/10.1016/i.psychsport.2007.01.005

Mérida, R., Serrano, A. \& Tabernero, C. (2015). Diseño y validación de un cuestionario para la evaluación de la autoestima en la infancia. Revista de Investigación Educativa, 33(1), 149-162. https://doi.org/10.6018/rie.33.1.182391

Mira, J. E., Padrón, A. L. \& Andrés, S. M. (2010). Validación mediante el método Delphi de un cuestionario para conocer las experiencias e interés hacia las actividades acuáticas con especial atención al Windsurf. Ágora para la educación física y el deporte, 12(1), 75-94.

Muñiz, J. (1998). Teoría clásica de los tests. Madrid: Pirámide.

Navarro-Patón, R., Barreal, P. \& Basanta, S. (2016). Relación entre el autoconcepto físico y el disfrute en las clases de educación Física en escolares de Educación Primaria. Journal of Sport and Health Research, 8(2), 151-162.

Ortega, E., Jiménez, J., Palao, J. \& Sainz, P. (2008). Diseño y validación de un cuestionario para valorar las preferencias y satisfacciones en jóvenes jugadores de baloncesto. Cuadernos de Psicología del Deporte, 2, 39-58.

Pozo, M. T., Gutiérrez, J. \& Rodríguez, C. (2007). El uso del método Delphi en la definición de los criterios para una formación de calidad en animación sociocultural y tiempo libre. Revista de investigación educativa, 25(2), 351-366.

Ramos, R., Giménez, A. I., Lapaz, E. \& Muñoz, M. A. (2006). Cuestionario de evaluación de la autoestima para Educación Primaria (A-EP). Madrid: TEA Ediciones.

Robles, A., Robles, J., Giménez, F. J. \& Abad, M. T. (2016). Validación de una entrevista para estudiar el proceso formativo de judokas de élite. Revista Internacional de Medicina y Ciencias de la Actividad Física y el Deporte, 16(64), 723-738.

Romero-Martín, M. R., Gelpi-Fleta, P., Mateu-Serra, M. \& Lavega-Burgués, P. (2017). Influencia de las prácticas motrices sobre el estado emocional de estudiantes universitarios. Revista Internacional de Medicina y Ciencias de la Actividad Física y el Deporte, 17(67), 449-466. 
Rose, E., Larkin, D., Hands, B., Howard, B. \& Parker, H. (2009). Evidence for the validity of the Children's Attraction to Physical Activity Questionnaire (CAPA) with young children. Journal of Science and Medicine in Sport, 12(5), 573-578. https://doi.org/10.1016/j.jsams.2009.05.009

Ruiz-Ariza, A., Ruiz, J.R., De la Torre-Cruz, M., Latorre-Román, P. \& Martínez-López, E.J. (2016). Influencia del nivel de atracción hacia la actividad física en el rendimiento académico de los adolescentes. Revista Latinoamericana de Psicología, 48(1), 42-50. https://doi.org/10.1016/i.rlp.2015.09.005

Schmider, E., Ziegler, M., Danay, E., Beyer, L. \& Bühner, M. (2010). Is it really robust? Reinvestigating the robustness of ANOVA against violations of the normal distribution assumption. Methodology, 6 , 147-151. https://doi.org/10.1027/1614-2241/a000016

Scotto, S., Guillet-Descas, E., Procentese, F. \& Martinent, G. (2017). Construction and validation of the Sport Sense of Community in Adolescence Questionnaire (SSCAQ). Journal Community Psychology, 45, 783-795. https://doi.org/10.1002/jcop.21892

Thomas, J. R. \& Nelsson, J. K. (2007). Métodos de investigación en Actividad Física. Barcelona: Paidotribo.

Tuñon, I., Laiño, F. \& Castro, H. (2014). El juego recreativo y el deporte social como política de derecho. Su relación con la infancia en condiciones de vulnerabilidad social. Educación Física y Ciencia, 16(1), 1-16.

Viñals, A. \& Cuenca, J. (2016). Ocio entre pares en la era digital: percepción del ocio conectado juvenil. Revista de Psicología del Deporte, 25(2), 61-65.

Zurita-Ortega, F., Romero, C., Ruiz, L., Martínez, A., Fernández, M. \& Fernández, R. (2008). Influencia de las alteraciones raquídeas en la flexibilidad de los escolares. Revista Internacional de Medicina y Ciencias de la Actividad Física y el Deporte, 3(32), 282-298.

\section{(9) $\odot \Theta \Theta$}

This title is licensed under a Creative Commons Attribution-NonCommercial-NoDerivs 4.0 Unported License. 